\title{
Case C-243/15 Lesoochranárske zoskupenie VLK v Obvodný úrad Trenčín
}

\author{
EU:C:2016:838
}

\section{Matthijs van Wolferen}

Universtiy of Groningen, The Netherlands

m.j.van.wolferen@rug.nl

\section{Introduction}

One of the more interesting cases of recent years has to be the Slovak Bears case. ${ }^{1}$ This case dealt with the position of a Slovak environmental non-governmental organisation (ENGO) in administrative proceedings in relation to requested derogations in the hunting and permitting law regarding the European Brown Bear. Due to the nature of the Slovak administrative law, the ENGO would only be awarded certain rights if it could get the qualification of 'participant' in the proceedings. When this status was denied, the ENGO was de facto barred from taking part in the discussion regarding the requested derogations, but equally would not be notified of developments; would not get access to documents, and would not be able to contest the outcome of the administrative process. The ENGO was denied the status of participant and contested this denial.

The case rose to prominence when the Slovakian Supreme Court sent a preliminary reference to the Court of Justice of the European Union (CJEU) which referenced the obligations of the Slovakian government under the Aarhus Convention. ${ }^{2}$ This international agreement, signed both by the Member States and the EU, is well known for being an innovative attempt to solve the problems faced by many individuals and NGOs when trying to protect their living environment. It does so by committing its signatories to the securing and, where necessary, relaxing of the procedural rights of parties regarding access to information, participation in decision-making, and access to justice.

1 Case C-240/o9, Lesoochranárske zoskupenie VLK v. Ministerstvo životného prostredia Slovenskej republiky EU:C:2011:115 (Slovak Bears).

2 United Nations Economic Commission for Europe, "Convention on access to information, public participation in decision-making and access to justice in environmental matters" (available at <www.unece.org/fileadmin/DAM/env/pp/documents/cep43e.pdf>). 
The Slovak Bear case was of interest as it presented the Court with a case in which an international agreement interacted with European law in an area that has traditionally been regarded as off-limits for judicial intervention under the concept of 'procedural autonomy'. ${ }^{3}$ One of the most cited articles on this case has therefore rightly been titled: "Who is the Referee?". ${ }^{4}$ At the time of the Slovak Bear case, the theoretical possibilities of the cJEU to enforce the Aarhus Convention, which itself has a more conciliatory compliance mechanism, ${ }^{5}$ were of great interest not only to national ENGOs but equally so to the academics studying the Court's own approach to standing of public interest litigants. The facts surrounding the Slovak Bear case were enlivened by the fact that the Court itself does not have the best reputation when it comes to locus standi in non-economic cases. ${ }^{6}$

Given the above, it is safe to say that the resolution of the Slovak Bear case has drawn a lot of attention. ${ }^{7}$ The Court of Justice did indeed find a way to

3 For a discussion on whether or not this concept does even still exist, the following contribution by Bobek is highly recommended: 'Why There Is No Principle of "Procedural Autonomy" of the Member States', The European Court of Justice and the Autonomy of Member States (Intersentia 2012).

4 Jan H Jans, 'Who Is the Referee? Access to Justice in a Globalised Legal Order: A Case Analysis of ECJ Judgment C-240/og Lesoochranárske Zoskupenie of 8 March 2011' (2011) 4 REALaw 85.

5 The Aarhus Convention makes use of the Aarhus Convention Compliance Committee, a non-judicial body that aims to help signatories in attaining compliance with the Convention. See: Veit Koester, 'The Compliance Committee of the Aarhus Convention, and Overview of Procedures and Jurisprudence' (2007) 37 Environmental Policy and Law 83.

6 Jerzy Jendrośka, 'Aarhus Convention and Community Law: The Interplay' (2005) 2 Journal for European Environmental \& Planning Law 12; Jan H Jans, 'Did Baron von Munchhausen Ever Visit Aarhus? Some Critical Remarks on the Proposal for a Regulation on the Application of the Provisions of the Aarhus Convention to EC Institutions and Bodies' <http://papers.ssrn .com/sol3/papers.cfm?abstract_id=956602 > accessed 19 March 2014; Marc Pallemaerts, The Aarhus Convention at Ten: Interactions and Tensions Between Conventional International Law and EU Environmental Law (Europa Law Publishing 2011); Ludwig Krämer, 'The EU Courts and Access to Environmental Justice', Environmental Law Dimensions of Human Rights (oup Oxford 2015).

7 B Muller, 'Access to the Courts of the Member States for NGOs in Environmental Matters under European Union Law: Judgment of the Court of 12 May 2011 - Case C-115/og Trianel and Judgment of 8 March 2011 - Case C-240/og Lesoochranarske Zoskupenie' (2011) 23 J Environmental Law 505; Mariolina Eliantonio, 'Case C-240/og, Lesoochranárske Zoskupenie VLK v. Ministerstvo Životného Prostredia Slovenskej Republiky, Judgment of the Court of Justice (Grand Chamber) of 8 March 2011, Nyr, and Case C-115/o9, Bund Für Umwelt Und Naturschutz Deutschland, Landesverband Nordrhein-Westfalen eV v. Bezirksregierung Arnsberg (Intervening Party: Trianel Kohlekraftwerk Lünen GmbH \& Co. KG) Judgment of the Court of Justice (Fourth Chamber) of 12 May 2011, Nyr.' (2012) 49 Common Market Law Review 767; 
enforce the Aarhus Convention by way of the Habitat Directive. This has been the point on which most of the subsequent discussion focussed. The Supreme Court of Slovakia in its reference, posed two relevant questions: Is it possible to recognise that Article 9(3) of the Aarhus Convention has direct effect as it has become part of the acquis, but no legislative measures by the (then) Community have been undertaken? ${ }^{8}$ Is it possible to recognise Article 9(3) Aarhus Convention as having direct effect as Community law ${ }^{9}$ The reasoning behind the questions points to the classical approach of the Court to international agreements. The Aarhus Convention is a Mixed Agreement on a shared competence. ${ }^{10}$ As such, both Member States and EU are bound to the obligations laid down in the Aarhus Convention. However, as environmental policy is a shared competence, the Member States are competent to regulate in this area as long as the EU has not undertaken any measures. ${ }^{11}$ By its questions, the Slovak Court is, in fact, asking the CJEU whether in its opinion Slovakia is free to set rules on access to justice, or whether an act of the Community precludes this.

As the attempts by the Community to regulate access to justice in the Member States had failed, ${ }^{12}$ there was no immediate indication that Article 9(3) Aarhus Convention fell under the auspices of the Community and the Court. However, the Court reasoned that in this case the procedure relates to the protection of a species that was explicitly placed on the list annexed to the Habitats Directive. ${ }^{13}$ As a consequence, the proceedings fell within the scope

Ludwig Krämer, 'Comment on Case C-240/og Lesoochranárske Zoskupenie VLK: Access to Justice in Environmental Matters: New Perspectives (See Page 402)' (2011) 8 Journal for European Environmental \& Planning Law 445.

8 Article 9 Aarhus Convention aims to secure the right of access to justice for individuals and organisations that seek to protect the environment. There are three clauses in the article that aim to specify situations and applicants accordingly. As such, as will be demonstrated, Article 9(2) Aarhus Convention deals with applicants seeking to secure their rights under Article 6 Aarhus Convention (right to participate in decision-making). Article 9(3) Aarhus Convention aims to secure a broader to access to justice, albeit with a greater margin of appreciation for signatories to embed the access to justice against acts and omissions in contravention of provision of environmental law in the national legal system. The third question goes to the effect of an affirmative answer in the two questions mentioned.

10 Szilárd Gáspár-Szilágyi, ‘EU Member State Enforcement of "Mixed” Agreements and Access to Justice: Rethinking Direct Effect' (2013) 40 Legal Issues of Economic Integration 163.

11 Case C-459/03 Commission v. Ireland (MOX Plant) EU:C:2006:345 para. 86 and further.

12 See сом $/ 2003 / 624 /$ FINAL "Proposal for a Directive of the European Parliament and of the Council on access to justice in environmental matters".

Annex vi (a) as per para. 53 Case C-240/og. 
of Community law. It furthermore reasoned that even though the proposal to regulate 9(3) Aarhus Convention had failed, and Regulation 1367/2006 only sought to implement the Convention for the Institutions, ${ }^{14}$ this signalled a broader commitment of the Community to the Aarhus Convention. Furthermore, under this broader commitment, far-reaching diverging opinions on the interpretation thereof are unwanted. The Court was, therefore, competent to rule on the direct applicability of Article 9(3) Aarhus Convention. It judged the wording of this article to be too broad to be directly applicable within the meaning given to that term by the case law. However, it did relate to the Slovakian Supreme Court that given the scope and meaning of the Convention and the obligation under the Habitat Directive to protect the Brown Bear, Article 9(3) Aarhus Convention should be interpreted in such a way as to ensure effective judicial protection. The ENGO should as such be awarded the possibility to initiate proceedings. This brief summary of this complicated case illustrates why it became of such importance. The Court itself acknowledged that the Union had not undertaken any successful measures to implement Article 9(3) of the Aarhus Convention. Still, it took upon itself the task to assess whether this clause had an effect on the Member State's legal order, even going so far as to give an interpretation of what that effect should be. This is all on the basis of the Habitats Directive and the broad commitment to the Aarhus Convention. The situation brings to mind on the one hand, he discussions on the applicability of the Charter (when is there an application of Eu law?) ${ }^{15}$ but on the other hand a strong sense of judicial activism if not an act ultra vires. As has been the case in other areas of law, it takes another case for the Court of Justice to further refine and illustrate its reasoning. ${ }^{16}$ The case under discussion, which interestingly deals with the same actors, is just that. Due in part to the phrasing of the question of the referring court, this new Slovakian case offered the Court a chance to take into account not only its previous judgment but also place its

14 Regulation $1367 / 2006 / \mathrm{EC}$ on the application of the provisions of the Aarhus Convention on Access to Information, Public Participation in Decision-making and Access to Justice in Environmental Matters to Community institutions and bodies (Aarhus Regulation) oJ L 264, 13 .

15 See Case C-617/10, Åklagaren v Hans Åkerberg Fransson EU:C:2013:105.

16 See for instance the Court's case-law on Citizenship, which started with Case C-135/08 Rottmann, escalated with Case C-34/og, Ruiz Zambrano, both of which now fit in the wider context of McCarthy and Dereci: Niamh Nic Shuibhne, 'Case C-434/og, Shirley McCarthy v. Secretary of State for the Home Department, Judgment of the Court of Justice (Third Chamber) of 5 May 2011; Case C-256/11, Dereci and Others v. Bundesministerium Fur Inneres, Judgment of the Court of Justice (Grand Chamber) of 15 November 2011' (2012) 49 CMLRev 349. 
reasoning in the context of the right to access to justice such as it exists in the Charter. As will be briefly demonstrated, it is still possible to have widely diverging opinions on the new developments in this area of EU law. This is evident for example, in the Opinion of the Advocate General who takes a different approach to the case, focusing more on the individual elements and their place in the constitutional framework of the Union and reaches different conclusions.

2

The Case

\subsection{The Facts}

The current $L Z$ case (the ENGO is formally called Lesoochranárske zoskupenie $V L K$ which translates to the Forest Protection Association VLK; called $L Z$ for short in the judgment) concerns the Strážov Mountains, an area of which has been designated as a special protection area (SPA) under the Birds Directive (Directive $79 / 409 / \mathrm{EEC}$ ) in 2004. ${ }^{17}$ Part of the mountain reservation was also included on the list of sites of Community importance pursuant to the Habitats Directive. ${ }^{18}$

Biely Postok a.s. is a company that breeds deer for, amongst other things, hunting purposes near the Strážov Mountains SPA. On 18 November 2008, LZ is notified by the district authority of Biely Postok's request to be allowed to build an enclosure for these deer on parcels of land that are within the SPA. After receiving further information, as per its request, $L Z$ asked for a stay of proceedings as observations offered by the Service for Natural Protected Areas, ${ }^{19}$ indicated grounds for the denial of the request. In April 2009, $L Z$ was denied the status of 'party to the proceeding', triggering the complex constellation of events that would lead to the preliminary question under discussion.

The district authority in Trenčín would not grant $L Z$ the status of 'party to the proceeding' as the law in Slovakia accorded parties such as ENGOs the status of 'interested person'. ${ }^{20}$ This was confirmed in the administrative appeal to this decision on the first of June 2009, and became final on the $10^{\text {th }}$ of June that same year. On that same day, the permit for Biely Postok was accorded. The following day, $L Z$ brought an action against the district authority's decision

17 Then Directive 79/409/EEc On the Conservation of Wild Birds, amended in 2009 to Directive $2009 / 147 / \mathrm{EC}$.

18 Commission Decision 2008/218/EC OJ L 77, 106 adopting a first updated list of sites of Community importance for the Alpine biogeographical region pursuant to Council Directive 92/43/EEC (OJ L 206, 7).

19 Part of an governmental agency, similar to a park service.

20 Paragraph 82(3) Law No. 543/2002 on the protection of nature and the landscape. 
at the Regional Court in Trenčín. That court stayed the proceedings as the aforementioned Case C-240/og Lesoochranárske zoskupenie was still pending. Upon pronouncement of that case, the Regional Court annulled the decisions of the district authority by judgment of 23 August 2011. However, this decision by the Regional Court was overturned and sent back by the Supreme Court of the Slovak Republic, in a large part due to the finality of the decision given by the district authority on 10 June. Within Slovak law, the Supreme Court also noted, there exists a procedure for an applicant to be granted the status of 'omitted party', but this procedure should be initiated within three years after the contested decision has become final. ${ }^{21}$

The Regional Court annulled the decision of 10June 2009 again, this time on the ground that the district authority had acted prematurely in taking its decision, as the legal proceedings regarding the status of $L Z$ were still in motion at the time of the decision. Yet this decision by the Regional Court was again set aside by the Supreme Court by way of a judgment on 12 September 2012, based on the same reasoning it employed in its previous ruling. As the Regional Court undertook its third assessment of the case, it dismissed $L Z$ 's claim to be awarded the status of 'party to the proceeding' and stated that it was not obliged to notify the applicant of the possibility to be awarded an 'omitted party', as the three-year term of expiration had passed. Against this judgment of 23 November 2013, the ENGO appealed again before the Supreme Court, referencing its rights under the Aarhus Convention, Article 47 of the Charter of Fundamental Rights of the EU (the Charter) and Article 6(3) of the Habitats Directive, in the light of the judgement in Case C-24o/og. It is in this case that the Supreme Court decided to make a preliminary reference to the CJEU as it considers the permit system such as it exists under the Slovakian Civil Administration Code to potentially exclude the possibility for public participation in decisions that have an impact on the environment.

\subsection{The Question}

Given the particularities of the situation, the question posed by the referring court is complex due to the elements it seeks to incorporate:

Is it possible to guarantee the right to an effective remedy and to a fair trial, affirmed in Article 47 of the Charter, in the event of a purported breach of the right to a high level of environmental protection established under the conditions laid down by the European Union, mainly by Directive 92/43 (particularly [of the right] to help obtain the public's opinion on a

\footnotetext{
21 As part of the Slovak Civil Procedural Code, not the Administrative Procedural Code under Article $25 \mathrm{ob}(2)$.
} 
project which could have a significant impact on special areas of conservation falling within the European ecological 'Natura 200o' network), and the right invoked by the appellant (as a not-for-profit association active in the protection of the environment at national level) under Article 9 of the Aarhus Convention, within the limits indicated by the Court of Justice in its judgment of 8 March 2011, Lesoochranárske zoskupenie (Case C-240/og, EU:C:2011:125), where the national court terminates the judicial review proceedings in a case concerning the review of a decision refusing to grant [that association] the status of party in an administrative procedure regarding the issuing of a permit, as has happened in the present case, and invites [that association] to lodge an appeal against its having been excluded from that administrative procedure?

The question can be divided into a number of elements. The Advocate General took a formalist approach and gives a thorough overview of each of the legal elements. As such, she addresses the Aarhus Convention, the rights under Article 6 and Article 9 of that Convention, the Habitats Directive and the Charter as separate elements that she then applied to the complex situation described above. A more casuistic approach can also be taken, which in the opinion of the author is at least in part followed by the Court, by separating the issue of the right of participation of the ENGO in the permit procedure, and the subsequent possible denial of justice due to the procedural rules laid down in the Code of Administrative Procedure and the Code of Civil Procedure.

It is proposed that, given the depth of the analysis by the AG and the manner in which she ties this case to the significance of Case C-240/og, a brief overview of the Opinion is given before further analysis of the judgment takes place.

\subsection{The $A G$}

The Opinion of the AG is of interest due to the well structured and analytical manner in which she approaches the case. Where, as will be demonstrated, the Court takes a more straightforward approach, AG Kokott deconstructs the complex procedure down to its basic elements. As such, she offers a ninepoint analysis structured along the two main points of the case: the rights of an ENGO and access to justice. The Opinion offers a view of the national perspective. Kokott rebuts the claims of both Slovakia and Biely Potok that the subject matter of the case should be limited, given the finality of the initial proceedings under Slovak law. The AG illustrates the state of unclarity of the procedure that still existed at the time of the oral proceedings before the Court of Justice. ${ }^{22}$ The status of that initial procedure is the fulcrum on which the AG 
builds her case regarding the nature of Article 6(3) Habitats Directive and the rights on which $L Z$ should be able to rely.

This leads to one of the main substantive differences between the Court and the AG in their reasoning. When discussing the role of the Aarhus Convention in the current dispute, the AG relies on a complex framework in which the Convention can be used as a standard of review. Beginning with the assertion that the Court has "unlimited jurisdiction to interpret Articles 6 and 9(2) of the Convention", due to the implementation of the Convention in the Habitats Directive, the AG is of opinion that Article 6(1)(b) is of direct effect due to the specific wording in the French authentic text of the Convention. This is especially interesting as the AG (and later the Court) acknowledges that the enclosure, which is the point of contention in the original dispute, is not mentioned as a project falling under the Annex I referred to by Article 6(1)(b) Aarhus Convention. ${ }^{23}$

The other substantive difference is the AG analysis of the interplay between the rights to a fair trial as laid down in Article 47 Charter, and the right to an effective remedy set out by Article 9(4) Aarhus Convention. The AG begins by stating that the responsibility for sufficient judicial protection lies primarily with the Member State. Given the absence of EU rules on this point, the AG focuses on the principle of effectiveness rather than on a substantive analysis of the Slovak procedural codes. ${ }^{24}$ Given that approach, it is therefore not remarkable that the AG comes to the conclusion that, even though the procedure has a complicated nature, the system as envisaged by the Slovakian national procedural law, nor the three year time limit are necessarily precluded by Article 47 Charter or Article 9(4) Aarhus Convention. As will be demonstrated below, it is on this point that the Court's interpretation will be the most far reaching, thereby coming to a conclusion that is manifestly different from the AG's careful deliberation.

\subsection{The Court of Justice}

As mentioned, the Court of Justice take a more casuistic approach. To that end, it first sets out the requirements under the Habitats Directive in conjunction with the Aarhus Convention relating to the right of participation for ENGOs, further discussed in section 2.4.1. Having established this framework, the Court than proceeds with an analysis of the procedural rules in the light of Article 9 (specifically paras. 2 and 4) Aarhus Convention and Article 47 Charter, further discussed in section 2.4.2. The reasoning being that $L Z$ 's right to access

\footnotetext{
23 Ibid Points 64-68.

24 Ibid Point 97.
} 
to justice is a fundamental safeguard for the exercise of $L Z$ 's right to public participation.

\subsubsection{The Right of Access to Participation}

The Court starts by setting out the conditions under national law by which the rights laid down in the Habitats Directive can be effectuated. It comes to the conclusion that $L Z$ can only apply against a decision, such as the one in the current procedure, which potentially infringes upon Article 6(3) Habitats Directive, if it has the status of 'party to the procedure'. The Court establishes that the idea behind the system set out in Article 6(3) of the Directive is to assure that plans or projects are initiated on the basis of the most accurate scientific knowledge available. Through this system it is believed that the highest level of environmental protection will be able to be achieved in line with the goals set out in Article 2(2) of the Directive. Although Article 6(3) does not create rights, the Court is of opinion that it would go against the binding effect of directives laid down in Article $288 \mathrm{TFEU}$, if it were not possible for individuals to rely on it, or were national courts not to take it into considerations in the assessment of the legality of a project such as the under discussion. It then follows that, in line with the Habitats Directive, the opinion of the general public should be asked, where appropriate. This is a direct implementation of the Aarhus Convention. ${ }^{25}$ The Court then sets out the manner in which Article 6 of the Aarhus Convention aims to implement the pillar of participation to decision making into the EU legal order. It is then possible to interpret Article 6 of the Habitats Directive in the light of the Aarhus Convention in order to assess the extent of $L Z$ 's rights and the obligations place on the local authorities.

Foregoing a discussion on the nature of $L Z$, but automatically accepting its status as falling under the concept of 'the public concerned' within the meaning of the Convention, ${ }^{26}$ the Court brings together the Aarhus Convention and the Habitats Directive. The enclosure is not one of the projects mentioned in Annex I to the Aarhus Convention, for which public involvement is systematically required. However, as the local authority initiated an authorisation procedure within the meaning of Article 6(3) of the Habitats Directive, the procedure falls under the system envisaged by tArticle 6(1)(b) Aarhus Convention. Although there is a considerable margin of appreciation for the Member State in the implementation of a system of participation, this only applies to the

\footnotetext{
25 Case C-243/15 Paras. 43-45.

26 Article 2(5) Aarhus Convention.
} 
manner in which that right to participate in proceedings can be implemented, the right itself cannot be derogated from. ${ }^{27}$

\subsection{The Right to Access to Justice}

Having thus established that the right to participation and that the manner in which it has been implemented in the current case falls under Eu law, the Court states that within this context the Member State is obliged to provide an effective remedy to protect this right under Articles 4(3) and 19 TEU. Furthermore, in applying Eu law within the meaning of Article 51(1) Charter, the Court finds the jurisdiction to apply Article 47 Charter.

The standard by which the Court assesses the right to a remedy as stated in Article 47 Charter is that of Article 9(2) Aarhus Convention. This provision, which is an integral part of EU law, applies in situations regarding the use of Article 6(1)(b) Aarhus Convention, which has been affirmed to be implemented by Article 6(3) Habitats Directive. As the Convention aims to offer wide access to justice, organisations such as $L Z$ should be able to rely on the right laid down by Article 9(2) Aarhus Convention to defend the rights awarded to them by EU environmental law. This entails being able to not only to challenge the decision whether an assessment of the site should take place, but also to have defects remedied through judicial means when such an assessment been undertaken. To this end, the Aarhus Convention not only requires access to justice, but also for these procedures to be adequate and effective. ${ }^{28}$

The Court conceded that it is in principle for the referring court to assess whether the system as described in the question complies with the principles set out by EU law and the Aarhus Convention. Yet it asserted its authority to "[...] deduce from the provisions of Eu law the criteria that the referring court may or must apply within the framework of Eu law."29 It thus sets out the requirements under Article 6(3) Habitats Directive, coming to a conclusion based on a "stringent authorisation criterion" which, together with the precautionary principle helps to protect the SPAs. ${ }^{30}$ The Court finds that although $L Z$ was able to participate in the proceedings, it did not have the possibilities to protect the integrity of the SPA it would have had, had it been awarded the status of 'party to the proceedings' from the outset. ${ }^{31}$ Furthermore, the possibility

27 Case C-243/15 Para. 48.

28 Case C-243/15 Paras. 59-62.

29 Ibid. Para. 64.

3o Ibid. Para. 66.

31 Ibid. Para. 67, the Court goes into greater detail regarding the specific possibilities of $L Z$ had it been awarded the status of 'party to the proceedings' in paragraph 69, making use 
of the applicant for the permit to be the only party in the authorisation process, as it is the only party to be automatically awarded the status of 'party to the proceeding', is deemed likely to be at odds with the goal of the system, to achieve a high level of environmental protection. Therefore, the interpretation of national law such as in the current procedure is not "designed to prevent specific adverse effects on the integrity of the site". ${ }^{32}$ The question posed by the referring court is thus answered in the negative.

\section{Explanation}

The complex interplay that occurs between these three laws, the Habitats Directive, the Charter, and the Aarhus Convention, is perhaps best illustrated by the effort of the AG to put each of these elements in its place. When reading each segment, the question posed by Jans rises again. ${ }^{33}$ To put that question slightly differently: Why should the Court of Justice be able to uphold the standard set by the Aarhus Convention? The question remains compelling, and yet it is the author's assertion that the Strážov Mountains case offers an insight in what the Court is trying to build. It should be kept in mind that the reasoning of Court is rather far-reaching, as the essence of the question is in fact:

Is it unnecessarily burdensome for an ENGO to go through a secondary procedure, to achieve a status to contest the primary procedure in which it was unable to reach that goal due to procedural rules. ${ }^{34}$

The issue at hand is therefore subtly different from the Slovak Bear case. In that case, the possibility that $L Z$ could rely directly on the Aarhus Convention was at issue. Even though the EU had not successfully undertaken any steps to implement the Article 9(3) of the Convention in any way, shape or form, the Court considered that the effectiveness of the protection of the brown bear would be diminished if $L Z$ did not have the rights conferred upon them by the Convention. It considered itself competent to come to this conclusion, as the brown bear was placed on Annex IV(a), on protected species. ${ }^{35}$ Thus, the

\footnotetext{
of the documents that it has received in relation to the administrative procedure before the local authority.

$32 \quad$ Ibid. Para. 72.

33 Jans (n 3$)$.

34 Triggering the AG's references to Kafka and Cervantes.

35 Case C-240/og para. 37-38.
} 
proceedings fell under the auspices of Eu law and that of the Court. Looking at the general system and the EU's intentions in relation to the implementation of the Convention, the Court stated that it had the jurisdiction to interpret Article 9(3) Aarhus Convention and whether the article had direct effect. ${ }^{36}$ In that case as in the current one, the Court gave an extensive reading of what the right to access to justice should entail, one could argue, producing a similar effect to harmonising where the Commission had failed.

In the current case, there is room for additional nuance. The question before the Court primarily deals with the system of access to participation in the decision-making process. As both the AG and the Court make clear, this right, laid down in Article 6 Aarhus Convention, has been implemented by the EU in a number of pieces of legislation, some of which follow the wording of the Convention verbatim. ${ }^{37}$ Therefore, the traditional manner in which the Court of Justice asserts its authority over the interpretation of a clause in a mixed agreement on shared competences is not out of place. However, the manner in which the Court asserts that Article 6 Habitats Directive and its partner, Article 6 Aarhus Convention, are applicable is again reminiscent of the Slovak Bear case. It should be remembered that the enclosure requested by Biely Potok a.s. does not fall under the list of projects mentioned in Annex I of the Aarhus Convention for which public participation is systematically required. It rather falls within the meaning of Article 6(1)(b) Aarhus Convention, ${ }^{38}$ which leaves a certain margin of appreciation for the signatories. It is therefore not necessarily logical that the Court can claim interpretative authority on the status of Slovakian procedural law under Article 6(1)(b) Aarhus Convention, given the procedural autonomy of the Member State. The manner in which the Court claims authority is clearly in the spirit of the Slovak Bear case. Member States have a certain margin of appreciation in establishing whether the Aarhus public participation framework applies as regards projects fall under Article 6(1)(b) Aarhus Convention. However, when the national authority chooses to make use of the system under Article 6(3) Habitats Directive, it is implementing EU

$36 \quad$ Ibid. para. 45 .

37 Case C-243/15 para. 58, where the Court gives the example of the EIA Directive that has been amended to mirror the Aarhus Convention. (Directive 85/337/EEC OJ L175, 40 as amended by Directive 2003/35/EC OJ L 156, 7).

38 "Shall, in accordance with its national law, also apply the provisions of this article to decisions on proposed activities not listed in annex I which may have a significant effect on the environment. To this end, Parties shall determine whether such a proposed activity is subject to these provisions;". 
law. ${ }^{39}$ This triggers the authority of the Court to interpret Article 6(1)(b) Aarhus Convention.

This implementation equally opens the door to the wide scope of review that the Court uses in determining whether the complicated system in the Slovakian Administrative and Civil Procedural Codes infringes the principle of a fair trial under the Charter. It is not the first time that Article 47 Charter has been linked to Article 9 Aarhus Convention, as AG Kokott has used it in her Opinion in Edwards, where she linked the rights of the individual set out in Article 47 Charter to the public interest. ${ }^{40}$ Interestingly, the Court does not enter into such a debate on the nature of the Article, rather it immediately used the Aarhus Convention as a standard by which it can apply the right to a fair trial in this case. With the invocation of Article 47 Charter, the referring court may have, so to speak, dug the grave for its own procedural law. The wide scope of the Charter gives the Court the possibility to assess the effectiveness of the procedure through Aarhus tinted glasses, without having to go again into a discussion on the nature of Article 9(2) Aarhus Convention. This is of interest, as the Article 47 Charter is notoriously difficult to apply through judicial review, especially regarding standing requirements. ${ }^{41}$

The result is a judgment which heavily relies on the wording and intent behind the Aarhus Convention, in particular that of Articles 9(2) and 9(4). This leads to an assessment of Slovakian procedural law by the Court of Justice instead of a referral back to the Supreme Court, allowing the referring court to implement the Court's finding in the national legal order. Although tailored to the, rather specific, circumstances of the case, this gives us an interestingly detailed list of conditions that the Court sees as essential in both the right of participation in decision-making as the right for access to justice. Case C-243/15 Lesoochranárske zoskupenie VLK v Obvodný úrad Trenčín can be seen as a refinement of its predecessor, giving a taste of what is possible when three instruments of rights protection are used in harmony by the CJEU.

\footnotetext{
39 See C-243/15 para. 47.

40 Case C-26o/11 Edwards and Pallikaropoulos v. Environmental Agency EU:C:2012:645.

41 Consider the limitations mentioned by Prechal. It becomes clear that the Charter is effective where the right is obviously hindered, yet there are difficulties in the enforcement of a normative standard. Sacha Prechal, 'The Court of Justice and Effective Judicial Protection: What Has the Charter Changed?' in Christophe Paulussen and others (eds), Fundamental Rights in International and European Law (TMC Asser Press 2016) $151<$ http://link .springer.com/10.1007/978-94-6265-088-6_7> accessed 25 October 2016.
} 
With the Aarhus Convention applied under the principle of effectiveness, especially Article 9 Aarhus Convention through the interplay with Article 47 Charter, the Court has created an enforcement mechanism in the EU that is unknown in the Convention system, that makes use of the non-judicial Compliance Committee. The wide margin of appreciation regarding locus standi that has been traditionally awarded to Member States, even by the Convention itself, seems to have shrunk by a significant margin. This is a result of the Court acting resolutely in line with the scope and goals stated by the Convention. The effectiveness test gains a set of teeth, as the procedural rights of the Convention as interpreted by the ACCC often gives stricture guidance on implementation, where EU secondary legislation often remains silent. This empowers environmental NGOs to be an active partner in the enforcement of EU law, at a level that is unattainable for, for example, DG Env. ${ }^{42}$

Where in the Slovak Bear case, the Court seemed to take the approach that has been taken by AG Kokott in this case, it is clear that it now no longer sees the need for a meticulous discussion on the specific place of the Convention in the EU constitutional order. Nor does the Court enter into discussion on the relationship between this mixed agreement and its jurisdiction. The Aarhus Convention is an integral part of the acquis. As such the Court can interpret its effect in the European legal order. The effectiveness of the protection of the EU goal of a high level of environmental protection restricts severely the margin of interpretation for the (referring) courts as regards the standards that flow from the wording and scope of the Convention.

Critics will note how this seemingly collides with the Court's own rigid stance on the protection of the environment through direct access to judicial review for public interest litigants, such as $L Z$. However, here the complete system of remedies comes into view. ${ }^{43}$ The Aarhus Convention, due to the nature of EU law and the place that international law takes in that system, can only affect the interpretation of secondary law. When it comes to the Treaty, which set out the system for judicial review of Union acts in Article 263 TFEU, the

42 Although it is possible for the Commission to enforce problems with participation in environmental decisions under the Habitats Directive under the 258 TFEU procedure, the sheer amount of information needed to find these infringements is unworkable. See in this journal: Ludwig Krämer, 'The Commission's Omission to Use Article 267 TFEU as a Tool to Enforce EU Environmental Law' (2016) 13 JEEPL 255.

Case 284/83 Parti écologiste “Les Verts" $v$ European Parliament EU:C:1986:166 para. 23. 
Court is severely limited in the extension of its scope. ${ }^{44}$ Similarly, the effects of the Charter are explicitly curtailed by the Explanations. ${ }^{45}$

Yet, the Court uses these tools to great effect on a Member State level. By treating the Aarhus Convention as an integral part of European law, and linking it to the obligation of the Member States for sincere cooperation under Article 4(2) TEU and their obligation to ensure the judicial protection of European rights under Article $19 \mathrm{TEU}$, the Court is decentralising the complete system of remedies regarding European environmental law. Slovak Bears, may at first glance seem as a leap in reasoning regarding the possibility for the Court of Justice to interpret international law on which no EU measures have taken place, but it is logical from the perspective of protection of an endangered species explicitly mentioned in the Habitats Directive. Likewise, the protection of the right to participate in the decision-making procedure not covered by either the Aarhus Convention or explicitly by the Habitats Directive may seem far reaching. Yet, as rightly remarked by the Court, it does justice to the spirit and wording of the Convention (and consequently the Directive) to whose compliance the Union is dedicated. By adding the element of Article 47 Charter in the Strážov Mountains case, the Court perhaps now sees a chance to add substantive requirements to an area of procedural autonomy where it has been traditionally hard to gain traction, standing requirements.

It is argued that the strict enforcement by the Court of Justice of the guarantees envisioned by the Aarhus Convention as regards access to justice vis-à-vis national procedural law contributes to the creation of a complete system of remedies, as it has always promised. ${ }^{46}$ The existence of a complete system of remedies has always had difficulty to convince public interest litigants. ${ }^{47}$ The direct access to the Court has been proven to be almost inaccessible, and the practice concerning national courts use of Article 267 TFEU does not seem to balance that inaccessibility. ${ }^{48}$ Although this may do justice to the concept

44 Matthijs van Wolferen, 'The Limits to the CJEU's Interpretation of Locus Standi, a Theoretical Framework' (2016) 12 Journal of Contemporary European Research <http://jcer .net/index.php/jcer/article/view/782> accessed 5 January 2017.

Art. $5^{2}$ para. 2 Charter and the corresponding text in the Explanations: '[...] such rights remain subject to the conditions and limits applicable to the Union law on which they are based, and for which provision is made in the Treaties'.

46 Case 284/83 Parti écologiste “Les Verts" $v$ European Parliament EU:C:1986:166 para. 23.

47 Roland Schwensfeier, 'Individual's Access to Justice under Community Law' (Diss, University of Groningen 2009).

48 Veerle Heyvaert, Justine Thornton and Richard Drabble, 'With Reference to the Environment: The Preliminary Reference, Procedure, Environmental Decisions and the Domestic Judiciary' [2014] The Law Quarterly Review 413. 
of procedural autonomy, it detracts from the sense of an integrated European legal order, with a complementary integrated judicial order. The Commission, following indications from the Court, argued the existence of a functional tiered judicial system, where issues of EU law are in fact a matter of implementation at a national level. Therefore, national courts should be the starting point for the review procedure in the complete system of remedies. Cases such a C-240/og and now C-243/15 are in fact the first indication that the Court is pursuing such a tiered system rather than only arguing it. Placed in the arguments put forward at the time of the ACCC proceedings against the European Union, ${ }^{49}$ it can be argued that the Court sees easier access to justice on a Member State level as a possible point of access to the Court of Justice. A line of reasoning that may be supported by the help in that respect from its cousine in Strasbourg, which recently found the failure to refer a case to the CJEU in certain situations to be a breach of Article 6 ECHR..$^{50}$ Therefore, the Strážov Mountains case may superficially seem to be a logical extension of the CJEU previous case-law in the Slovak Bears case, where it sees itself as the referee on Aarhus Convention related matters. The reasoning of the Court in the present case seems to indicate that this station has been passed, and it is now making full use of the Convention to effectuate greater access to justice in the member states for ENGOS. In effect, this signifies the Court's further move towards a truly integrated, tiered judicial system. This could be a first step, but it should be kept in mind that this development will only have an effect is the all other elements in the system are aligned accordingly. Most importantly, the conditions that control national courts possibilities to make a reference, or indeed the conditions under which they are able to derogate from this obligation are do not seem capable to guarantee judicial protection. ${ }^{51}$ Under these circumstances, the Strážov Mountains case can be an interesting first step, yet if this is the road down which the Court wishes to travel, a lot of roadwork will need to be done.

49 See Case ACCC/C/2008/32 European Union, communication from the Party concerned dd. 11.06.2009.

5o Schipani and Others v. Italy no. 38369/og Chamber Judgment, [2015] ECHR 735.

51 On the difficulties for redressing shortcomings in judicial protection at national level in the context of environmental plans and programmes, see: Squintani L and Plambeck E.J.H, 'Judicial Protection against Plans and Programmes Affecting the Environment: A Backdoor Solution to Get an Answer from Luxembourg' (2016) 13 J. Eur. Environ. Plann. Law Journal for European Environmental and Planning Law 294 On the Commission's failure to make effective use of this procedure, see $\operatorname{Kramer}(\mathrm{n} .42)$. On national courts reluctance in making use of Article 267 TFEU see Heyvaert, Thornton and Drabble (n. 48). 